\title{
IMPLEMENTATION STRATEGIES AND PERFORMANCE OF NON- GOVERNMENTAL ORGANIZATION PROJECTS IN RWANDA: A CASE OF FAITH VICTORY ASSOCIATION PROJECTS, KAYONZA DISTRICT
}

\author{
Bosco N. KWIZERA ${ }^{1 *}$, Dr. Paul MUNENE ${ }^{2}$, \\ ${ }^{1}$ School of Business and Economics, Business Administration, Project Management, Mount Kenya University, Kigali \\ Email:kwizerabosco@hotmail.com \\ ${ }^{2}$ Senior Lecturer, Mount Kenya University, Kigali, Rwanda Email: munenepaul1@gmail.com
}

*Corresponding Author: -

Email: kwizerabosco@hotmail.com

\begin{abstract}
: -
The general objective of this study is to assess the effect of implementation strategies on performance of NGO projects with specific reference to Gikuriro project implemented by Faith Victory Association in Kayonza. The specific objectives were to examine the community empowerment, capacity building and community participation on performance of $N G O$ projects. The study played a significant role to various people including researcher, the management of the project itself, government and academic researchers. When conducting this study, a descriptive research design with two mixed methods such quantitative and qualitative approach was used. The target population was project beneficiaries who were given questionnaires and the project administrators as well as staff who were interviewed. In total the total target population was 13250 people, from whom a sample of 400 was selected using Sloven's formula. The study used a stratified random sampling technique and data were collected using questionnaires and interviews. The analysis of data was done using SPSS version 22.0 and Microsoft Excel. Both inferential (correlation and regression analysis) and descriptive statistics (mean and standard deviation) were used. The findings pertaining research objectives showed that the community empowerment, capacity building and community participation affect performance of NGO projects. On community empowerment $95 \%$ of the respondents Community training, Farmer learning schools, Village NS as capacity building strategies affected performance of NGO projects. The study findings further showed that 89\%) of respondent's community empowerment through saving groups affected performance of NGO projects. The study findings showed the community participation in utilities or consumable types agriculture was e $61 \%$ community participation animal type of assets wwas $24 \%$ community participation in agricultural tools represent $47 \%$ while community participation in house and land $54.8 \%$. When assessing the relationship between implementation strategies and performance of NGO projects with specific reference to Gikuriro project implemented by Faith Victory Association in Kayonza, the study findings showed that there is a significant relationship between implementation strategies and performance of NGO projects presented a positive correlation with $p$-value $(r=0.092, p=0.067),(r=-0.008, p=0.000),(r=0.016, p=0.000),(r=0.042, p=$ $0.000),(r=0.006 . p=0.000)$ and $(r=-0.036, p=0.000)$. The study concludes that community empowerment, capacity building and community participation on performance of NGO projects are important strategies for ensuring project sustainability. The study, recommended that NGO funded projects in Kayonza District should be have clear guiding implementation strategies and procedure, community participation strategy in place and integrating monitoring in their implementation strategies at all stages.
\end{abstract}

Keywords: - Implementation strategies, Project performance, Non-governmental Organizations, Rwanda

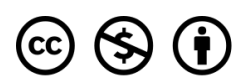




\section{INTRODUCTION}

Non-Governmental Organizations projects continue to be common in every entity of existence additionally to the policy makers in regards to both locally and internationally developments, however, the deprived performance of projects and the disappointments of project appeared to be a common scenario (Gregg \& Ana,

2016). Nearly all the projects were not accomplished in the estimated timeline, quality and budget (Rotich, 2014). Just as mirrored by Ika, Diallo and Thuillier (2012) "project failures have become a routine with majority of the projects working under complexity of risks and uncertainties, external pressures, unforeseen actions, changing needs, unreliable restrictions and contradictory resources flow, all these are harmful to projects' success in NGO's.

Gikuriro project implemented by Faith Victory Association in Kayonza in its fourth year of implementation, however there are a number of challenges that it has run into; delayed fund from donor, less budget compared to the geographical coverage of the project and these had resulted in delays of project implementation, increased administrative budget and increased complains from beneficiaries (Faith Victory Association Annual report, 2020).

Various studies have been done world over on performance of Non-Governmental Organizations projects found that only half of projects succeed mainly due to implementation strategies adopted (Lavagnon, Amadou \& Denis, 2012). Studies done on effect implementation strategies and performance of NGO projects include Keene, (2007), Cooke-Davies, (2012) differentiates factors leading to the success of project management and factors leading to the success of a project as a whole, Nelson (2005), andThomas \& Fernandez (2008) distinguish between project management success and project success.

From this, it is clear that many studies have attempted to explore the success of project implementation. However, none of these scholars have looked at the effect implementation strategies and performance of NGO projects in Rwanda. Therefore, this study sought to fill the gap by evaluating the effect implementation strategies and performance of NGO projects with specific reference to Gikuriro project implemented by Faith Victory Association in Kayonza.

\subsection{Objectives of the study 1.1.1}

\section{General objective}

The general objective of the study was to establish the effect implementation strategies and performance of NGO projects with specific reference to Gikuriro project implemented by Faith Victory Association in Kayonza.

\subsubsection{Specific objectives}

(i) To examine the effect of capacity building on performance of Gikuriro project implemented by Faith Victory Association in Kayonza.

(ii) To determine effect of community empowerment on performance of Gikuriro project implemented by Faith Victory Association in Kayonza.

(iii) To establish the exent to which community participation affect performance of Gikuriro project implemented by Faith Victory Association in Kayonza.

\section{Review of Literature \\ 2.1 Implementation strategies}

World Bank. (2013) study on Provision of Social Services to the Poor and the Vulnerable in West Bank and Gaza. The study used descriptive research design where key stakeholders in a representative sample of client countries. The study found out that, Poverty rate in developed countries is low and the standard level of living is high, this is due to different development program activities and these countries normally operate in high performed activities, the example of these countries include United States of America, Japan China, England and others. The high rate of poverty is normally observed in low developed countries like Latin America where most of the population in Peru equivalent to 39\% live below the poverty line and in Brazil and Argentina where $2 \$$ a day is benefited by population, this turn into poverty line. Astudy done by Agba et al., (2014) to assess factors influencing poverty reduction programs in rural areas of Nigeria showed that NGOs plays the significant role in poverty reduction in terms of improving health, education, insurance and communication. The study encourages rural people to manage and allocate resources properly so as to achieve developmental programs.

\subsection{Performance of Non-Governmental Organization Projects}

Park (2012) investigated a setoff ten common factors and 188 individual factors influencing whole life performance of South Korean projects. The failure of many agricultural development programs in Nigeria could be traced to poor organizational structure at the grassroots level. The rural resource-poor farmers are isolated, undereducated and lack the means to win greater access to resources and market. The study further found that showed that the poorest farmers were excluded from activities and benefits due to the use of conventional mode of transfers aimed at boosting agricultural production and generating wealth for the rural community dwellers. There are many researchers found that the delay and cost are increased due to the confusion among project participants

Summer, (2009) studied project failure in the context of cost and attributed the failure to poor communication among the client and the project team members, inadequate financial resources, lack of motivation, tendering methods, poor project definition and infrastructure, poor project organization, environmental conditions and quality of project implementation. On analyzing the Kenyan project failure factors, he identified poor communication, little experience of the project managers, late procurement equipment, and slow project selection methods as being the major causes. 
Another study conducted by Chiazor (2012), Kanu (2003), and Chevron (2013) in Nigeria to assess the the contribution of NGO on rural economic development showed that the non-government organization plays important role in enhancing community benefits like income generating activities, education facilities, insurance, and improvement in wealth of society.

A field study conducted by Agba, Ogaboh; Akpanudoedehe, and Ocheni (2014) in Nigeria to determine activities of NGOs in rural areas showed that NGOs contribute to the transformation of economy throughout credit facilities, provision of advices to fight against poverty. As indicated, the NGOs provide trainings to rural communities on how to use and manage available resources.

\subsection{Community participation}

A study conducted by Uma, (2013) in India to assess the role of NGOs on poverty reduction showed that NGOs act as financial or microfinance institution to promote community capacity to operate and improve their living condition. Therefore, community become self-reliance and capable to undertake sustainable development in social working environment.

A survey done by Omogi (2014) in Korogocho to assess the factors influencing women empowerment on poverty reduction showed that $69 \%$ were in mixed poverty reduction and only $31 \%$ were only men who succeeded to reduce poverty, Women are more than men as they are involved in small business activities. Therefore, the standard level of living for women improved compared to those of men.

Purvis, Mao, \& Robinson, (2019) studied three pillars of sustainability: in search of conceptual origins. The three-pillar conception of (social, economic and environmental) sustainability, commonly represented by three intersecting circles with overall sustainability at the center, has become ubiquitous. The study revealed relevant historical sustainability literature and various critiques in the early academic literature of the economic status quo from both social and ecological perspectives in the United Nations. The study used popular three circles diagram appears to have been first presented by Barbier albeit purposed towards developing nations with foci which differ from modern interpretations. The study found out that to achieve the sustainable development, both public and private development initiatives need to cooperate which leads to poverty reduction. Within industrialized areas, sustainability is easily achieved and there is a balance between society, economic and environment.

\subsection{Community Empowerment}

With reference to the study conducted by Agba, et al., (2014) to assess factors influencing poverty reduction programs in rural areas of Nigeria showed that NGOs plays the significant role in poverty reduction in terms of improving health, education, insurance and communication. The study encourages rural people to manage and allocate resources properly so as to achieve developmental programs. Researcher raise the critical approach related to some areas of underdevelopment due to poor leadership. NGOs are not fully aware of such areas which require more attend for consideration.

Based on the study conducted by Kanu (2003), Chiazor (2012), and Chevron (2013) in Nigeria to assess the contribution of NGO on rural economic development showed that the non-government organization plays important role in enhancing community benefits like income generating activities, education facilities, insurance, and improvement in wealth of society. The overall criticisms and research gap identified is that the authors clearly indicates the role played by NGOs in rural area but ignore that poverty persist in urban areas. Therefore, NGOs need to be directed or initiate development activities within urban areas to assist poor people fight against poverty.

As indicated by Omogi (2014) on different factors leading men towards poverty alleviation strategies in Korogocho, the study focused on one way of self-help groups in slums. This study did not attempt to correlate how each of the variables related directly with each other. Studies that are vast in literature do not show any empirical evidence on how Rwanda NGO initiatives are contributing to poverty alleviation, irrespective of the significant contributions they provide. Such a knowledge gap merits an investigation so as to enable policy making process.

\subsection{Research Gap}

Many authors suggest project implementation strategy should be used by a project team as a guideline for effectively performing project activities (Patanakul, Shenhar \& Milosevic, 2012). Project success is typically assessed based on several dimensions and is driven by success factors (Baccarini, 2009; Collins \& Baccarini, 2014; Cooke-Davies, 2012; Mueller \& Turner, 2007). Each performance measure should have an evaluative mechanism (Texas Department of Transportation, 2011). Performance measures provide the basis for determining the degree of achievement of established objectives and when well chosen, they convey whether key objectives are achieved in a meaningful way for performance management. United States Agency for International Development (USAID, 2010).According to Belassi \& Tukel, (1996) only a few studies in the project management literature concentrate on the critical factors that affect project success or failure. The success factors are usually listed as either very general factors or very specific factors affecting only a particular project.

With reference to the study conducted by Agba et al., (2014) to assess factors influencing poverty reduction programs in rural areas of Nigeria showed that NGOs plays the significant role in poverty reduction in terms of improving health, education, insurance and communication. The study encourages rural people to manage and allocate resources properly so as to achieve developmental programs. Researcher raise the critical approach related to some areas of underdevelopment due to poor leadership. NGOs are not fully aware of such areas which require more attend for consideration. 
Based on the study conducted by Kanu (2003), Chiazor (2012), and Chevron (2013) in Nigeria to assess the contribution of NGO on rural economic development showed that the non-government organization plays important role in enhancing community benefits like income generating activities, education facilities, insurance, and improvement in wealth of society. The overall criticisms and research gap identified is that the authors clearly indicates the role played by NGOs in rural area but ignore that poverty persist in urban areas. Therefore, NGOs need to be directed or initiate development activities within urban areas to assist poor people fight against poverty.

As indicated by Omogi (2014) on different factors leading men towards poverty alleviation strategies in Korogocho, the study focused on one way of self-help groups in slums. This study did not attempt to correlate how each of the variables related directly with each other. Studies that are vast in literature do not show any empirical evidence on how Rwanda NGO initiatives are contributing to poverty alleviation, irrespective of the significant contributions they provide. Such a knowledge gap merits an investigation so as to enable policy making process.

\section{Materials and Methods}

This study used descriptive survey design. This particular design was ideal since the research entailed the collection and comparing of data from the phenomena at the same time of study. Mugenda \& Mugenda (2013) argue that descriptive survey design is appropriate where the overall objective is to establish whether significant relationship among variables exist at some point in time. The project beneficiaries are distributed in ten sectors FVA comprises total population of 50 employees 13250 beneficiaries in Kayonza. In this study, the sample size has been determined using Slovin's equation: $\mathrm{n}=\mathrm{N} / 1+\mathrm{Ne}^{2}$. Thus, the 400 respondents were selected, using stratified random sampling because they were categorized into the employees and beneficiaries in Kayonza project as distributed across 10 sectors.

Data analysis process included data sorting, editing, coding, or variable generation, data entry, cleaning, processing using SPSS 22.0 version. The quantitative data collected using the closed ended items was assigned ordinal values and analyzed using statistics of frequency tables, percentage Standard deviation and median values of the Likert 5-point scale rating. The findings were presented using tables, frequencies and percentages. Hypothesis was tested using Spearman's rank correlation, and frequency tables. The analysis also was determined using p-value $<0.005$ to assess the relationship of the study variables with help of Pearson rtho estimates was referred to in this model analysis. The algebraic expression of the regression model took the following form.

$$
y=\beta 0+\beta_{1} X_{1}+\beta_{2} X_{2}+\beta_{3} X_{3}+\varepsilon
$$

Where: $y=$ Performance of NGO project, $\beta 0=$ Constant, $\beta 1-\beta 3=$ Model Coefficients, X1: Capacity building, X2: Community empowerment and X3: Community participation and $\varepsilon 1=$ the unknown random error assumed as normally distributed.

\section{Research Findings \\ 4.1 Capacity building}

Table 4. 1: Participation in Farmer Field learning schools and Village nutrition schools

\begin{tabular}{lll}
\hline $\begin{array}{l}\text { Attendance to Farmer Field learning schools and Village nutrition } \\
\text { schools activities }\end{array}$ & Frequency & Percentage \\
\hline Once a month & 43 & $11 \%$ \\
Twice a month & 380 & $95 \%$ \\
3 times a month & 0 & $0 \%$ \\
4 times a month & 0 & $0 \%$ \\
Capacity building activities enjoyed most & 380 & $95 \%$ \\
Cooking demonstrations & 380 & $95 \%$ \\
Growth monitoring sessions & 231 & $58 \%$ \\
\hline
\end{tabular}

Source: Primary Data (2021)

The research findings as presented in Table 4.5 showed that $95 \%$ of the respondents attended the Nutrition and health training sessions twice a month; and among the programs most enjoyed in the training included cooking demonstration $380(95 \%)$, and growth monitoring sessions 380(95\%). These trainings are provided by the project to all members and in it empowerment program sessions are included as far as nutrition and health is concerned. The finding showed that majority attended these sessions and enjoyed the interaction and the child growth monitoring sessions.

Table 4. 2: Member of Farmer Field learning schools/ FFLS

\begin{tabular}{lll}
\hline $\begin{array}{l}\text { Member of Farmer Field } \\
\text { learning schools/ FFLS }\end{array}$ & Frequency & Percentage \\
\hline Yes & $\mathbf{3 4 4}$ & 86 \\
NO & $\mathbf{5 6}$ & 14 \\
\hline
\end{tabular}

Source: Primary Data (2021)

The study findings further showed majority $86 \%$ community members who belong to a Farmer Field Learning school received a package of trainings on how to improve on their agriculture practices. Such trainings involved Bio intensified agriculture techniques (BIAT). These findings imply that capacity building is 'human power and competencies' for 'positive change'. Other definitions for capacity building were elaborated by some respondents. 
A respondent said, it is the ability to look at oneself critically. Another respondent mentioned that capacity building is unfolding human potentials for continuous development. Understanding the meaning of the concepts is important to help the learners appreciate the essence of the process.

Table 4. 3: Presentation of Capacity building

\begin{tabular}{|c|c|c|c|c|c|c|c|}
\hline $\begin{array}{c}\text { Capacity building } \\
\text { implementation strategy }\end{array}$ & $\mathbf{S A}$ & Agree & Neutral & Disagree & SD & Mean & St. D \\
\hline $\begin{array}{l}\text { capacity building process great attention } \\
\text { should be given to } \\
\text { development of professionalism }\end{array}$ & $46.0 \%$ & $36.0 \%$ & $14.0 \%$ & $4.0 \%$ & 0 & 4.351 & 1.223 \\
\hline $\begin{array}{l}\text { Nutrition education program Capacity } \\
\text { building built positive revolution in human } \\
\text { thinking and action and change of mindset. }\end{array}$ & $25.0 \%$ & $51.0 \%$ & $3 \%$ & $16.0 \%$ & $5.0 \%$ & 3.001 & .861 \\
\hline $\begin{array}{l}\text { Farmer learning schools built positive } \\
\text { revolution in human thinking and action } \\
\text { and change of mindset. }\end{array}$ & $50.0 \%$ & $31.0 \%$ & $15.0 \%$ & 0 & $4.0 \%$ & 3.851 & .579 \\
\hline $\begin{array}{l}\text { Village nutrition schools built primarily } \\
\text { positive revolution in human thinking and } \\
\text { action and change of community mindset. }\end{array}$ & $25.0 \%$ & $56.0 \%$ & $19.0 \%$ & $0 \%$ & 0 & 3.767 & 1.286 \\
\hline
\end{tabular}

Source: Primary Data (2021)

Table 4.3 majorities of respondents $82 \%$ agreed that capacity building process, great attention should be given to development of professionalism with a mean of 4.351 and standard deviation of 1.223. For Nutrition education program capacity building built positive revolution in human thinking and action and change of mindset, $76 \%$ of respondents agreed with the statement with a mean of 3.001 and standard deviation of 0.861 . Respondents who agreed with the statement farmer learning schools built positive revolution in human thinking and action and change of mindset were $81 \%$ with a mean of 3.851 and standard deviation of $0.579 .81 \%$ of respondents agreed that village nutrition schools built primarily positive revolution in human thinking and action and change of community mindset at a mean of 3.767 and standard deviation of 1.286 .

Robson and Colin (2015) who opine that people are the drivers of change and these findings are supported by studies which suggest that projects on complex and changing context might need a slightly different approach toward project implementation strategies Andersen (2018), Remington \& Pollack (2017) advocated that project work can be executed in different ways, especially when it is not feasible to divide the project into next phases. They further opined that implementation strategies affect the performance of projects and the key ingredients of a successful program are those that come from people in reflection to what is best for the organization.

Table 4. 4: Model summary

\begin{tabular}{lllll}
\hline Model & $\mathrm{R}$ & $\mathrm{R}$ Square & Adjusted R Square & Std. Error of the Estimate \\
1 & 0.085 & 0.082 & 0.0801 & 0.050981 \\
\hline
\end{tabular}

The study had a general objective of analyzing the effect capacity building programs on the performance of NGOs projects. The results of the study indicated that capacity building only explain $8.5 \%$ ( R square $=0.085$ ) of the variance in project performance. This implies that $92.5 \%$ of the variance in project performance is explained by other factors outside the model used. These results indicate that though capacity building influences the project performance, this is significantly at low level, with this possibly attributed to various project performance elements that exists

Table 4. 5: Regression Coefficients of the Capacity building and performance of Gikuriro project

\begin{tabular}{lllllll}
\hline Model & \multicolumn{2}{l}{ Unstandardized Coefficients } & Standardized Coefficients & T & Sig. \\
& & B & Std. Error & Beta & & \\
2 & (Constant) & 1.801 & .483 & & 3.729 & .000 \\
\hline & Capacity building & .0006 & .089 & .007 & .69 & .483 \\
\hline
\end{tabular}

Source: Primary Data (2021)

\section{Dependent Variable: performance of Gikuriro project}

$y=\beta 0+\beta_{1} X_{1}+\varepsilon$ Becomes Performance of Gikuriro project $=1.801+.0006$ Capacity building From the above regression equation it was revealed that Capacity building on are holding to a constant zero, performance of Gikuriro project would stand at 1.801, a unit increase in Capacity building would lead to increase in performance of Gikuriro project by a factor of .0006 . 
4.2 Community empowerment strategy

Table 4. 6: Views of respondents pertaining community empowerment as implementation strategy

\begin{tabular}{|c|c|c|c|c|c|c|c|}
\hline $\begin{array}{rc}\text { Community } & \text { empowerment } \\
\text { implementation strategy }\end{array}$ & SA & Agree & Neutral & Disagree & SD & Mean & St. D \\
\hline $\begin{array}{l}\text { Economic strengthening program has } \\
\text { enabled community to acquire utilities, } \\
\text { house or land and agricultural tools }\end{array}$ & $72 \%$ & $21 \%$ & $3 \%$ & $4 \%$ & $0 \%$ & 4.45 & 0.12 \\
\hline $\begin{array}{l}\text { Economic strengthening program has } \\
\text { enabled community to improve their } \\
\text { household income and saving habit through } \\
\text { Access to loans }\end{array}$ & $90 \%$ & $7 \%$ & $2 \%$ & $1 \%$ & $0 \%$ & 4.73 & 0.16 \\
\hline $\begin{array}{l}\text { Health and nutrition program has enabled } \\
\text { nutrition practices }\end{array}$ & $65 \%$ & $20 \%$ & $10 \%$ & $0 \%$ & $5 \%$ & 4.29 & 0.12 \\
\hline $\begin{array}{l}\text { Economic strengthening program has } \\
\text { enhanced ability community to pay medical } \\
\text { insurance to all family members and Access } \\
\text { to health facilities }\end{array}$ & $46.0 \%$ & $36.0 \%$ & $14.0 \%$ & $4.0 \%$ & 0 & 4.351 & 1.22349 \\
\hline $\begin{array}{l}\text { Advocacy program has enable community } \\
\text { to lobby government to a access to health } \\
\text { facilities at short distance }\end{array}$ & $25.0 \%$ & $51.0 \%$ & $3 \%$ & $16.0 \%$ & $5.0 \%$ & 3.12 & .06104 \\
\hline
\end{tabular}

Source: Primary Data (2021)

Table 4.6 shows that majority of respondents $93 \%$ agreed that economic strengthening program has enabled community to acquire utilities, house or land and agricultural tools with a mean of 4.45 and standard deviation of 0.12 . For the statement that economic strengthening program has enabled community to improve their household income and saving habit through access to loans, $97 \%$ of respondents agreed with the statement with a mean of 4.73 and standard deviation of 0.16 . Respondents who agreed were $85 \%$ with a mean of 4.29 and standard deviation of $0.12 \%$ on the statement that health and nutrition program has enabled nutrition practices. $82 \%$ of respondents agreed that Economic strengthening program has enhanced ability community to pay medical insurance to all family members and access to health facilities with a mean of 4.351 and standard deviation of 1.22349 . Majority of respondents $76 \%$ agreed that advocacy program has enabled community to lobby government to a access to health facilities at short distance with a mean of 3.12 and standard deviation of .06104

4.3 Economic strengthening as Community empowerment Strategy Table 4. 7: Areas of saving facilities

\begin{tabular}{ccc}
\hline Presence areas of saving facilities & Frequency & Percentage \\
\hline SILC group & 323 & $89.0 \%$ \\
Bank & 8 & $2.0 \%$ \\
SACCO & 23 & $6.0 \%$ \\
In Household & 8 & $2.0 \%$ \\
Total & $\mathbf{3 6 2}$ & $\mathbf{1 0 0 . 0 \%}$
\end{tabular}

Source: Primary Data, (2021)

Research findings showed that $323(89 \%)$ saved in their NGO group i.e. SILC group though minor instances of saving in other institutions were present. This shows that the economic strengthening program implemented through the SILC groping had majority of the membership and influenced these members' behavior towards saving. As indicated, the study findings showed that saving habits enable production and is the means of finance for low income earners in Rwanda. Therefore, it enables saving groups to attain wealth and perform other social and economic benefits within working environment. The research findings showed that $89 \%$ save in informal schemes like saving and internal lending community groups while $2 \%$ of them normally save in their own house. Therefore, saving rate in formal financial sector is low which turn into insecurity. However, the according to the final report of the baseline survey for the Gikuriro program, families who saved in SILC groups were 31.4\% and those who saved from their homes were $41.8 \%$. Those who save via SILC increased by $57.6 \%$ and those who saved to their homes reduced by $39.8 \%$. This shows how project intervention increased the culture of internal savings and lending. 
Table 4. 8: Main sources of Income source Frequencies

\begin{tabular}{|c|c|c|c|c|c|}
\hline & \multicolumn{2}{|c|}{ Responses } & \multirow{2}{*}{\multicolumn{2}{|c|}{$\begin{array}{l}\text { Percent } \\
\text { Cases }\end{array}$}} \\
\hline & & $\mathrm{N}$ & Percent & & \\
\hline & Sale of agricultural produce & 114 & $26.0 \%$ & $28.0 \%$ & \\
\hline & Sale of livestock or livestock products & 7 & $1.0 \%$ & $1.0 \%$ & \\
\hline \multirow{5}{*}{$\begin{array}{l}\text { What are the main sources of income in } \\
\text { your house }\end{array}$} & day laborer & 271 & $64.1 \%$ & $67.0 \%$ & \\
\hline & ${ }^{n}$ Full time employment from any source & 4 & $0.0 \%$ & $1.0 \%$ & \\
\hline & Trading & 4 & $0.0 \%$ & $1.0 \%$ & \\
\hline & Small business & 19 & $4.0 \%$ & $4.0 \%$ & \\
\hline & Other & 4 & $0.0 \%$ & $1.0 \%$ & \\
\hline $\begin{array}{l}\text { Total } \\
\text { a. Dichotomy group tabulated at value } 1 \text {. }\end{array}$ & & 423 & $100.0 \%$ & $105.0 \%$ & \\
\hline
\end{tabular}

Source: Primary Data (2021)

According to Table 4.12 main source of income was daily labor 271(64.1\%) followed by sale of agricultural produces, 114(26\%). Small businesses also raised income for 19(4\%) of the respondents. The finding implies that majority of the respondents raised their income through small agricultural produce sells and daily labor majorly. In his study Roach (2011) capital was raised by SMEs through borrowing from banks and savings groups but most times households that practice agriculture farming have to sell their products to increase their saving.

Table 4. 9 Total amount of money that came into your household last month (income)

\begin{tabular}{llll}
\hline & & Frequency & Percent \\
\hline & None & 19 & 4.0 \\
& $1-1000$ & 143 & 35.0 \\
Total income as of last $1001-10000$ & 164 & 41.0 \\
month & $10001-20000$ & 53 & 13.0 \\
& $20001-49000$ & 21 & 5.0 \\
& Total & 400 & 100.0 \\
\hline
\end{tabular}

Source: Primary Data $(2021)$

A household had a monthly income of between 1000 and 10000 Rwf, 164(41\%) but also less than 1000 were many, $143(35 \%)$. The findings therefore indicate that majority of the respondents had daily labor such as working in a hiring farm, or selling produces on small baskets and this would raise a little money of up to about 10,000 Rwf a month. The Gikuriro project doesn't give these beneficiaries capital but empowers them to save and borrow money through saving groups (SILC) and this allowed them to start income generating activities/IGAs and also acquired basic HHs assets. The next question probed to determine the type of assets that they acquired.

Table 4. 10: Household has savings

\begin{tabular}{cccc}
\hline & & Frequency & Percent \\
\hline & No & 66 & 16.0 \\
household has savings & Yes & 334 & 83.0 \\
& Total & 400 & 100.0 \\
\hline
\end{tabular}

Source: Primary Data (2021)

The initiative emphasizes saving among their beneficiaries. The next questions inquired whether this culture had developed among the beneficiaries irrespective of the small income they were able to get monthly. Research findings on whether the household had a saving showed that 334(83\%) had a savings, which shows the adoption of saving culture, hence sustainability. It was also important to know who contributed to this saving.

Table 4. 11: Monthly total household savings

\begin{tabular}{llllll}
\hline Savings & & Frequency & Percent & Valid Percent & Cumulative Percent \\
\hline \multirow{4}{*}{ Valid } & not sure & 30 & 7.0 & 7.0 & 7.0 \\
& up to 1000 & 159 & 39.0 & 39.0 & 47.0 \\
& $1001-10000$ & 202 & 50.0 & 50.0 & 97.0 \\
& above 30000 & 9 & 2.0 & 2.0 & 100.0 \\
& Total & $\mathbf{4 0 0}$ & $\mathbf{1 0 0 . 0}$ & $\mathbf{1 0 0 . 0}$ & \\
\hline
\end{tabular}

Source: Primary Data (2021)

The amount saved was between 1001-10000 Rwf but even those with less than $1000 \mathrm{Rwf}$ did save. This finding is critical as it reveals that most saved almost what they earned. It is possible because the rural area provides other sources for sustenance like a garden one could get food for a day, thereby being able to save for targeted assets.

Table 4. 12: Household contribution to savings last month

\begin{tabular}{|c|c|c|c|c|}
\hline Contribution & Frequency & Percent & Valid Percent & Cumulative Percent \\
\hline No & 228 & 57.0 & 57.0 & 57.0 \\
\hline Valid & 172 & 43.0 & 43.0 & 100.0 \\
\hline Total & 400 & 100.0 & 100.0 & \\
\hline
\end{tabular}

Source: Primary Data (2021) 
Asked whether anyone contributed to the saving, 228(57\%) responded in the negative however a significant portion, $172(43 \%)$ in the affirmative. The finding indicates that the household head alone did not contribute to the saving, however other members also contributed. It could be said though beyond the interest of the current study that since there were many members in the household, they too had been influenced to practice saving. However, it is also possible that savings could have come from other sources such as relatives or friends.

Table 4. 13: Saving facilities

\begin{tabular}{lllll}
\hline Saving facilities & Responses & \multicolumn{2}{c}{ Percent of Cases } \\
& N & Percent \\
\hline & $\begin{array}{l}\text { 1 }=\text { SILC group } \\
\text { 2 }=\text { Bank }\end{array}$ & 323 & $89.0 \%$ & $92.0 \%$ \\
Where do you save & 8 & $2.0 \%$ & $2.0 \%$ \\
& 3 $=$ SACCO & 23 & $6.0 \%$ & $6.0 \%$ \\
Total & 5 In Household & 8 & $2.0 \%$ & $2.0 \%$ \\
\hline
\end{tabular}

Source: Primary Data (2021)

The initiative provided saving group through SILC however, different savings were also encouraged. To find out where they saved from and particularly to evaluate the initiative, the place of saving was asked. The findings are presented in Table 4.18. According to the finding, 323(89\%) saved in their NGO group i.e. SILC group though minor instances of saving in other institutions were present. This shows that the initiative significantly influenced these members behavior towards saving. They found it easier to implement the trainings through their SILC group than save in a bank or SACCO. The study findings in final report of the baseline survey for the Gikuriro program showed that families who saved in SILC groups were $31.4 \%$ and those who saved from their homes were $41.8 \%$. Those who save via SILC increased by $57.6 \%$ and those who saved to their homes reduced by $39.8 \%$. This shows how project intervention increased the culture of internal savings and lending. In this study, researcher intended to assess whether the project helped beneficiaries to increase the incomes by abilities to access loan. The information provided are presented in figure 4.1
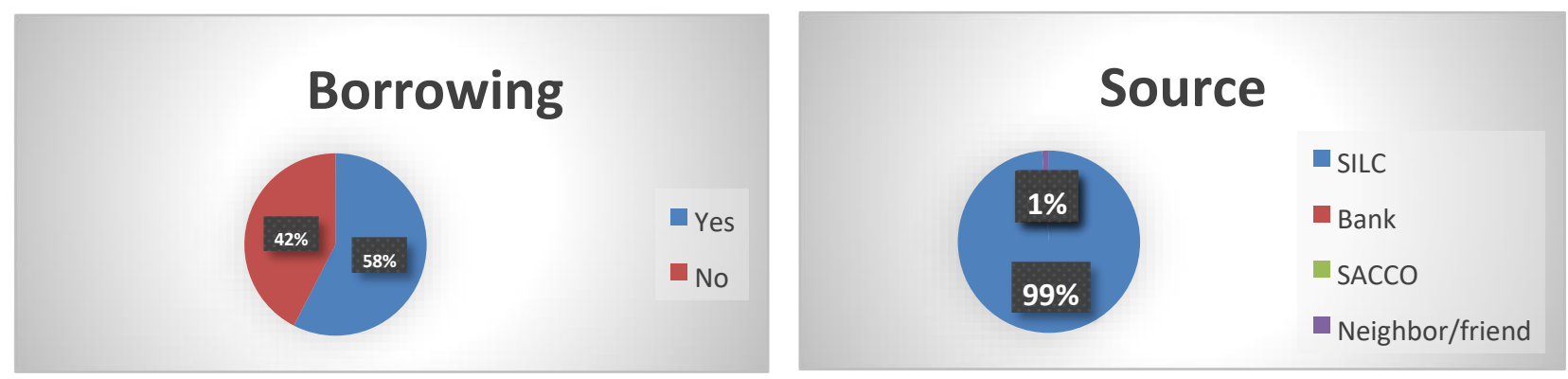

Source: Primary Data (2021)

Figure 4. 1: Borrowing and source

A total of 231(57\%) borrowed and $42 \%$ did not borrow. The source of borrowing was $99 \%$ SILC group. The finding shows that the initiative significantly influenced the member's. For the community members to meet their daily needs or invest in small business, they need to have access to financial services to cater for their needs. The culture of saving and lending promoted helped them to have access to cash through borrowing. Borrowing is an indication of risk taking for increasing capital in an investment and encouraged for those who are entrepreneurial (Schwienbacher \& Larralde, 2012). However, to meet daily needs people can borrow money to buy food, or access health care and pay a debt.

Table 4. 14: Sell asset Frequency

\begin{tabular}{|c|c|c|c|}
\hline & Responses & & Percent of Cases \\
\hline & $\mathrm{N}$ & Percent & \\
\hline in the past 6 monthsbuy food or basic household needs & 130 & $55.0 \%$ & $70.0 \%$ \\
\hline why sold asset assets to improve household income & 105 & $44.0 \%$ & $57.1 \%$ \\
\hline Total & 235 & $100.0 \%$ & $127.0 \%$ \\
\hline
\end{tabular}

Source: Primary Data (2021)

According to the finding, 130 (55\%) borrowed money to buy food or basic household needs, and 105(44\%)to increase on their assets, these two reasons indicate that majority were still struggling to meet their basic needs but at least the burden was being lightened through group saving where small loans were acquired easily to meet the needs. The initiative of Gikuriro is to empower its beneficiaries to meet their basic nutritional, hygiene, sanitation and other household needs. Such, is achieved through encouraging the beneficiaries to save so that they can have money to cater for the basic needs. 
The findings do support this objective since the responds indicate a change towards saving and self-empowerment through strenuous contributions to their groups for borrowing in time of need. The level of this change can also be seen in the investment that respondents made to enable them continue to earn. They bought relevant tools to use in their work, but also managed to buy other assets such as land, construct houses and improve their daily utilities.

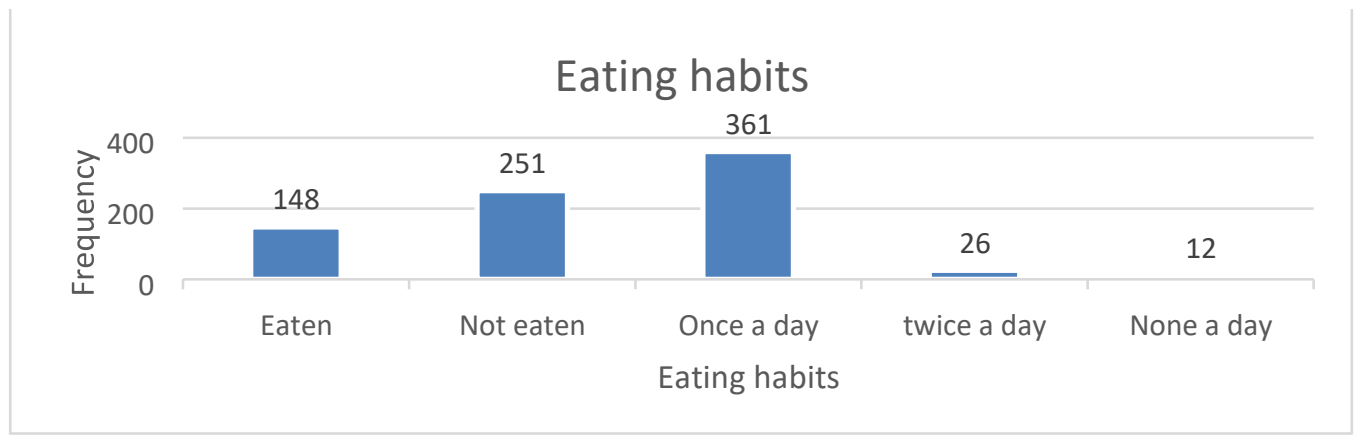

Figure 4. 2 Eating habit Source: Primary Data (2021)

In this study, the health and nutrition practices of respondents were determined to assess health conditions in ten selected sectors of Kayonza District. The findings assessed health condition within last 6 months and are presented in figure 4.2Findings related to health conditions were assessed in terms of eating habits in ten selected sectors of Kayonza District. The figure 4. 2 showed that 51 had missed eating lunch in the past 6 weeks while the remaining 148 had. When asked how many times they ate in a single day, 361 ate solid foods once a day, 26 twice a day and 12 had nothing to eat. The finding shows that majority of the beneficiaries eat solid foods only once a day. In this study, researcher was interested in assessing type of food benefited by population of Ten selected sectors of Kayonza District. The research findings showed different kinds of food mostly available in Kayonza District as result of contribution of NGO project. Table 4.20 present the results.

Table 4. 15: Type of food eaten

\begin{tabular}{|c|c|c|c|c|}
\hline Food & Type & Average & Percent & Percent of case \\
\hline Carbohydrate's sugar, honey & $\begin{array}{l}\text { Cereals (Rice, porridge, Bread, } \\
\text { ugali, roots and tubers, etc }\end{array}$ & 290 & $27 \%$ & $73 \%$ \\
\hline Animal protein & $\begin{array}{l}\text { Animal source foods (Meat,), } \\
\text { fish, eggs, milk and its products }\end{array}$ & 66 & $6 \%$ & $17 \%$ \\
\hline Plant proteins & $\begin{array}{l}\text { Legumes (beans, peas, soya } \\
\text { beans, ground nuts...) }\end{array}$ & 361 & $33 \%$ & $90 \%$ \\
\hline Vitamin & Fruits and vegetables & 241 & $22 \%$ & $60 \%$ \\
\hline Others & $\begin{array}{l}\text { Food with oil/fried food?, tea } \\
\text { and coffee etc }\end{array}$ & 128 & $12 \%$ & $32 \%$ \\
\hline Total & & 1086 & $100 \%$ & $272 \%$ \\
\hline
\end{tabular}

Source: Primary Data (2021)

According to Table 4.16 the most eaten type of food was protein followed by carbohydrates and vitamins. This shows diet diversity that makes a balanced diet. The initiative trains beneficiaries to balance their diet and they had acquired skills on choosing foods required for healthy living. The finding supports this irrespective of the poverty levels, and this proves a change in behavior towards eating nutritious foods available in their communities. In this study assessing health insurance status among project beneficiaries remained important to determine role played by NGO project in ten selected sectors of Kayonza District. The information collected showed that the project beneficiaries where able to meet their health insurance, they were asked to indicate whether they have health insurance. The findings are presented in Table 4.21 .

Table 4. 16: Health insurance status

\begin{tabular}{cccccc}
\hline Statement & & Frequency & Percent & Valid Percent & $\begin{array}{c}\text { Cumulative } \\
\text { Percent }\end{array}$ \\
\hline \multirow{2}{*}{ Valid } & No & 54 & 13.0 & 13.0 & 13.0 \\
& Yes & 345 & 86.0 & 86.0 & 100.0 \\
Missing & Total & 399 & 99.0 & 100.0 & \\
Total & System & 1 & .0 & & \\
\hline
\end{tabular}

Source: Primary Data (2021) 
According to the findings, 345(86\%) had a health insurance while 54(13\%) did not. The finding shows that majority had acquired health insurance.

Table 4. 17: Insurance type

\begin{tabular}{lllll}
\hline Which insurance do you have? & No & \multicolumn{3}{l}{ Yes } \\
\cline { 2 - 5 } & Count & Row N \% & Count & Row N \% \\
\hline Community based health insurance & 47 & $11.0 \%$ & 352 & $88.0 \%$ \\
RAMA & 399 & $100.0 \%$ & 0 & $0.0 \%$ \\
MMI & 399 & $100.0 \%$ & 0 & $0.0 \%$ \\
Private health insurance & 395 & $98.0 \%$ & 4 & $1.0 \%$ \\
Others specify & 399 & $100.0 \%$ & 0 & $0.0 \%$ \\
\hline
\end{tabular}

Source: Primary Data (2021)

According to Table 4.22, 352 (88\%) had health insurance provided through community-based health insurance (CBHI). Table 4. 18: Use of health facility services

\begin{tabular}{|c|c|c|c|c|}
\hline \multicolumn{4}{|c|}{ Responses } & \multirow[t]{2}{*}{ Percent of Cases } \\
\hline & & $\mathbf{N}$ & Percent & \\
\hline \multirow{4}{*}{$\begin{array}{l}\text { Did and why did } \\
\text { visit health facility }\end{array}$} & $\begin{array}{l}\text { If yes }(1=\text { yes, sought the treatmen } \\
\text { time skip to F6) }\end{array}$ & $\mathrm{n} 250$ & $80.0 \%$ & $81.0 \%$ \\
\hline & $\begin{array}{l}\text { If yes }(2=\text { sought treatment but it } \\
\mathrm{u}_{\text {late })}\end{array}$ & s37 & $11.0 \%$ & $12.0 \%$ \\
\hline & $\begin{array}{l}\text { If yes }(3=\text { no did not seek treatme } \\
\text { Go to F5) }\end{array}$ & $\wedge 20$ & $6.0 \%$ & $6.0 \%$ \\
\hline & If yes $\left(4=\right.$ don't know $^{\wedge}$ skip to F6) & 4 & $1.0 \%$ & $1.0 \%$ \\
\hline $\begin{array}{l}\text { Total } \\
\text { Dichotomy group tal }\end{array}$ & ated at value 1 & 311 & $100.0 \%$ & $100.0 \%$ \\
\hline
\end{tabular}

Source: Primary Data (2021)

Accordingly, for the 311 who visited health facilities, $250(80 \%)$ sought treatment on time $11 \%$ of respondents faced some delays while $6 \%$ did not seek treatment. The results shows that community members has increased knowledge on the importance of visiting health facilities on time to seek for treatment.

Table 4. 19: Failed to visit facility Frequencies

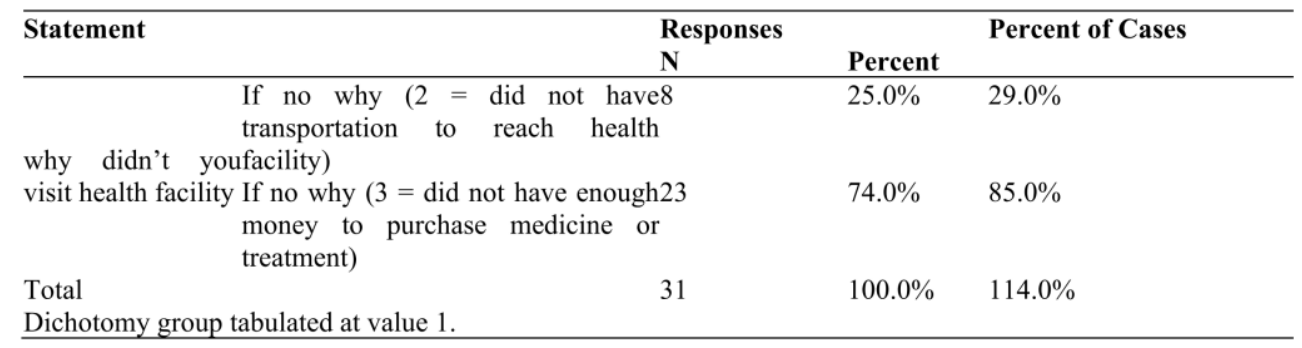

Source: Primary Data (2021)

The findings show that for the 31 who didn't visit facilities, they did because they didn't have enough money, 23(74\%) and $8(25 \%)$ did not have transport to reach the facility. In their report WHO (2012) found that in Africa access to health facilities is affected by lack of transport, the location of the facility and the inadequacy of equipment in these facilities.

Table 4. 20: Regression Coefficients of Community empowerment and performance of Gikuriro project

\begin{tabular}{|c|c|c|c|c|c|}
\hline \multirow[t]{2}{*}{ Model } & \multicolumn{2}{|c|}{ Unstandardized Coefficients } & \multirow{2}{*}{$\begin{array}{l}\text { Standardized } \\
\text { Coefficients } \\
\text { Beta }\end{array}$} & \multirow[t]{2}{*}{$\mathbf{T}$} & \multirow[t]{2}{*}{ Sig. } \\
\hline & B & Error & & & \\
\hline (Constant) & 1.557 & .364 & & 3.519 & 0.010 \\
\hline $\begin{array}{l}\text { Community } \\
\text { empowerment }\end{array}$ & 0.218 & .072 & 0.271 & 1.897 & 0.043 \\
\hline
\end{tabular}

Source: Primary Data (2021)

Dependent Variable: performance of Gikuriro project $y=\beta 0+\beta 2 X 2+\varepsilon$ Becomes performance of Gikuriro project $=1.557+.0218$. Community empowerment, From the above regression equation it was revealed that community empowerment on are holding to a constant zero, performance of Gikuriro project would stand at 1.557, a unit increase in community empowerment would lead to increase in performance of Gikuriro project by a factor of 0.218. 


\subsection{Community Participation}

Table 4. 21: Perception on Community Participation as implementation strategy

\begin{tabular}{|c|c|c|c|c|c|c|c|}
\hline $\begin{array}{l}\text { Community Participation as implementation } \\
\text { strategy }\end{array}$ & $\mathbf{S A}$ & Agree & Neutral & Disagree & SD & Mean & St. D \\
\hline $\begin{array}{l}\text { Economic strengthening, Nutrition education and } \\
\text { Farmer learning schools program are successful } \\
\text { when planning involves all the stakeholders. }\end{array}$ & $0 \%$ & $78.0 \%$ & $14.0 \%$ & $2.0 \%$ & $6 \%$ & 3.96 & 0.11 \\
\hline $\begin{array}{l}\text { Community participation as implementation strategy } \\
\text { has no influence on project success. }\end{array}$ & $65 \%$ & $20 \%$ & $10 \%$ & $0 \%$ & $5 \%$ & 4.29 & 0.12 \\
\hline $\begin{array}{l}\text { All the stakeholders understand the details of the } \\
\text { projects since it is well communicated. }\end{array}$ & $72 \%$ & $21 \%$ & $3 \%$ & $4 \%$ & $0 \%$ & 4.45 & 0.12 \\
\hline $\begin{array}{l}\text { Community participation strategy improve } \\
\text { performance and success of projects }\end{array}$ & $90 \%$ & $7 \%$ & $2 \%$ & $1 \%$ & $0 \%$ & 4.73 & 0.16 \\
\hline
\end{tabular}

Source: Primary Data (2021)

From the table above, $78 \%$ of the respondents were in agreement that Economic strengthening, Nutrition education and Farmer learning schools program are successful when planning involves all the stakeholders with mean of 3.96 and stnadrd deviation of $0.11,65 \%$ of the respondents were in agreement that stakeholder involvement was critical for successful project performance with mean scores 4.29. On statement that all the stakeholders understand the details of the projects since it is well communicated $75 \%$ stongly agreed with Mean of 4.45 while Community participation strategy improve performance and success of projects $90 \%$ stongly agreed

\subsection{Performance of NGO Project}

Table 4. 22: Perception on Performance Of NGO Project

\begin{tabular}{llllllll}
\hline Performance of NGO project & SA & Agree & Neutral & Disagree & SD & Mean & St. D \\
\hline $\begin{array}{l}\text { Project is executed and finished inside expected } \\
\text { time span.. }\end{array}$ & $78 \%$ & $10 \%$ & $4 \%$ & $4 \%$ & $4 \%$ & 4.72 & 1.07 \\
$\begin{array}{l}\text { The finished project activities typically meet the } \\
\text { necessary degree and quality tasks standard of } \\
\text { beneficiaries }\end{array}$ & $0 \%$ & $73.7 \%$ & $12 \%$ & $10 \%$ & $4.3 \%$ & 4.01 & 1.28 \\
$\begin{array}{l}\text { Project activities are finished within the agreed } \\
\text { cost }\end{array}$ & $20 \%$ & $10 \%$ & $23 \%$ & $62 \%$ & $5 \%$ & 2.89 & 3.79 \\
\hline
\end{tabular}

Source: Primary Data (2021)

From Table above $78 \%$ of respondent strongly agreed that project is executed and finished inside expected time span, $73.7 \%$ respondent agred that the finished project activities typically meet the necessary degree and quality tasks standard of beneficiaries while $62 \%$ disagreed that Project activities are finished within the agreed cost.

\subsection{Inferential statistics}

Table 4. 23: Correlation between implementation strategies and performance of NGO projects

\begin{tabular}{|c|c|c|c|c|c|}
\hline & & $\begin{array}{l}\text { Capacity } \\
\text { building }\end{array}$ & $\begin{array}{l}\text { Community } \\
\text { empowerment }\end{array}$ & $\begin{array}{l}\text { Community } \\
\text { participation }\end{array}$ & $\begin{array}{l}\text { Performance NGO of } \\
\text { project }\end{array}$ \\
\hline \multirow{4}{*}{ Capacity } & Pearson Correlation & 1 & .82 & .61 & -.63 \\
\hline & & .000 & .000 & .000 & .000 \\
\hline & $\begin{array}{l}\text { Sig. (2-tailed) building } \\
\mathrm{N}\end{array}$ & 400 & 400 & 400 & 400 \\
\hline & Pearson Correlation & .82 & 1 & .520 & .73 \\
\hline \multirow{4}{*}{$\begin{array}{l}\text { Community } \\
\text { empowerment }\end{array}$} & Sig. (2-tailed) & .067 & .000 & .000 & .000 \\
\hline & & 400 & 400 & 400 & 400 \\
\hline & $\mathrm{N}$ & & & & \\
\hline & Pearson Correlation & .61 & .520 & 1 & -.65 \\
\hline \multirow{3}{*}{$\begin{array}{l}\text { Community } \\
\text { participation }\end{array}$} & Sig (2-tailed) & .000 & .000 & .000 & .000 \\
\hline & Sig. (2-talled) & 400 & 400 & 400 & 400 \\
\hline & $\mathrm{N}$ & & & & \\
\hline \multirow{4}{*}{$\begin{array}{l}\text { Performance of } \\
\text { NGO project }\end{array}$} & Pearson Correlation & -.63 & .73 & -.65 & 1 \\
\hline & & .000 & .000 & .000 & .000 \\
\hline & Sig. (2-tailed) & & & & \\
\hline & $\mathrm{N}$ & 400 & 400 & 400 & 400 \\
\hline
\end{tabular}

Source: Primary Data (2021) 
According to the finding the Capacity building had moderate negative correlation with performance of NGO projects $(\mathrm{r}=$ $-0.63, p=0.000)$, Community empowerment had strong positive correlation with performance of NGO projects $\mathrm{r}=0.73 \mathrm{p}=.000$ Community participation had moderate negative correlation with performance of NGO projects $-.65 \mathrm{p}=.000$

Table 4. 24: Model summary

\begin{tabular}{llll}
\cline { 2 - 4 } & Model R Square & Adjusted R Square & Std. Error of the Estimate \\
1 & .784 & .781 & .04589 \\
\hline
\end{tabular}

Source: Primary Data (2021)

From the model summary table, $\mathrm{R}$ squared value is 0.781 equivalent to $78.1 \%$. this is an indication that implementation strategies captured by this study accounts for $78.1 \%$ of the variations in performance of NGO projects.

Table 4. 25: ANOVA

\begin{tabular}{llllll}
\hline Model & & Sum of Squares & Df & F & Sig. \\
\hline 1 & Regression & 43.565 & 4 & 90.501 & .000 \\
& Residual & 21.453 & 396 & & \\
& Total & 64.918 & 400 & & \\
\hline
\end{tabular}

Source: Primary Data (2021)

Dependent Variable: performance of NGO projects

In the ANOVA table, model had a significance level of 0.00 which shows that the data is ideal for making a conclusion on the population's parameter as the value of significance ( $p$-value) is less than $5 \%$. The model between implementation strategies and performance of NGO shows that model was significant since the pvalue was less than 0.05 without the interaction term, $\mathrm{F}(4,396) 90.501, \mathrm{p}<.000$. The significance value was less than 0.05 an indication that the model was statistically significant.

Table 4. 26: Model Coefficients

\begin{tabular}{lcccc}
\hline & Unstandardized Coefficients & & & \\
Model & $\mathrm{B}$ & Std. Error & $\mathrm{T}$ & Sig. \\
2 (Constant) & & .117 & .118 & .000 \\
Capacity building & .387 & .086 & 7.680 & .001 \\
Community empowerment & .243 & .068 & 1.786 & .012 \\
Community participation & .184 & .057 & 4.676 & .006 \\
\hline
\end{tabular}

Source: Primary Data (2021)

Dependent Variable: performance of NGO projects

The regression model $y=\beta 0+\beta_{1} X_{1}+\beta_{2} X_{2}+\beta_{3} X_{3}+\varepsilon$ Becomes performance of NGO project $=.387+.243$ Capacity building+ .184 Community empowerment +.122 Community participation. From the above regression equation it was revealed that capacity building community empowerment and community participation on are holding to a constant zero , performance of NGO would stand at 387, a unit increase in Capacity building would lead to increase in performance of NGO projects by a factor of 0.243 a unit increases in Community empowerment would lead to increase in performance of NGO projects by a factor of 0.184 while a unit increase in Community participation would lead to increase in performance of NGO projects by a factor of 0.122

\subsection{Hypothesis Testing}

The first null hypothesis was to $\mathrm{H}_{01}$. There no significant relationship between community empowerment and performance of Gikuriro project implemented by Faith Victory Association in Kayonza. According to table 4.31 the results shows that capacity building had $\mathrm{p}=.001<0.05$ hence we fail to reject null hypothesis and conclude that findings reveal that there is no significant relationship between community empowerment and performance of Gikuriro project implemented by Faith Victory Association in Kayonza.

The second null hypothesis was to $\mathrm{H}_{02}$ Community empowerment has no significant effect on performance of Gikuriro project implemented by Faith Victory Association in Kayonza. According to table 4.31 the results shows that community empowerment had $\mathrm{p}=0.012>0.05$ hence we reject null hypothesis and conclude that community empowerment has significant effect on performance of Gikuriro project implemented by Faith Victory Association in Kayonza.

The third null hypothesis was to $\mathrm{H}_{03}$ There no significant relatioinship between community participation and performance of Gikuriro project implemented by Faith Victory Association in Kayonza. According to table 4.31 the results shows that community participation had $\mathrm{p}=0.006<0.05$ hence we fail to reject null hypothesis and conclude that findings reveal that 
there is no significant relatioinship between community participation and performance of Gikuriro project implemented by Faith Victory Association in Kayonza.

\subsection{Discussion of Results}

The current research conducted in ten selected sectors of Kayonnza District among project staff revealed that through different strategies of FVA towards achieving community development goals, the project beneficiaries have managed to benefit from Nutrition and health programs as indicated by $95 \%$ of surveyed respondents who reported that capacity building strategy had moderate negative correlation with performance of NGO projects $(r=-0.63, p=0.000)$, Community empowerment strategy had strong positive correlation with performance of NGO projects $\mathrm{r}=0.73 \mathrm{p}=.000$ while community participation strategy had moderate negative correlation with performance of NGO projects $\mathrm{r}=-.65 \mathrm{p}=.000$. This is in line with Agba et al, (2014) on implementation strategies and performance of NGO shows that model was significant implying that Non-Governmental Organizations (NGOs) plays significant role in poverty reduction. The study further Agba et al, study found that NGOs strategies influence development in rural communities.

The findings of the study were also similar to Chiazor (2012) and Chevron (2013) to assess the NGO implementation strategy contribution to economic development in the rural communities. The study revealed that NGOs practices are contribute to economic development in rural communities. This is supported by key informant interviews conducted in Kayonza District where participants reported to have improved on their agriculture practices through the implementation strategies such as farmer field learning, bio intensified agriculture techniques (BIAT) and economic strengthening strategy. This was supported by the study conducted by Devi (2013) on the contribution of non-government organization towards poverty alleviation in India, microfinance institutions were ranked as important players to build capacity building of low income earners throughout financial support, advices and proper allocation of resources to reduce the poverty issues.

\subsection{Conclusion}

In conclusion, Based on the findings, it can be concluded that capacity building strategies such Community training, Farmer learning schools and Village nutrition schools improve project implementation and its efficiency Additionally, NGO's projects are highly influenced by capacity building strategy especially in relation to method of delivery and content disseminated to the communities. Finally project managers cannot simply attain to project success while ignoring human capacity. On community empowerment it can be concluded that proper beneficiary empowerment through economic strengthen, by developing saving culture and growing beneficiary household assets. This will enable them to access health insurance and quality health care. Advocacy as a means of empowerment is required in order to influence decision making.

The study concludes that community participation strategy is an important aspect in the project life cycle and should not only be done at the beginning of community development projects but a continuously process throughout the project life. Further, it requires deliberate community participation strategy to create the conditions of success for a project.

\subsection{Acknowledgement}

First, I thank God for the abundant blessings for having enabled me to complete my studies. I would also like to express my special appreciation to my lecturers of Mount Kenya University for their intellectual inputs that helped me compile this research. My sincere appreciation also goes to class in Masters of Business Administration for their support and cooperation. Sincere thanks go to my respondents from FVA Gikuriro Project, in Kayonza District who willingly participated in the research, without your cooperation, this research would not have been possible. Lastly, I am immensely grateful to my relatives and friends for their emotional support.

\section{References}

[1].Agba, A. , Ogaboh; Akpanudoedehe, J. \& Ocheni, S. (2014). Financing Poverty Reduction Programmes in Rural Areas of Nigeria: The Role of Non-Governmental Organisations (NGOs). In International Journal of Democratic and Development Studies (IJDDS) (Vol. 2, Issue 1). http://www.rcmss.com.

[2].Devi, R. U. (2013). An analytical study on the role of ngos in the poverty reduction of india. Researchers World, 4(4), 127. https://www.questia.com/library/journal/1P3-3140834441/an-analytical-study-on-the-roleof-ngos-in-thepoverty

[3].OECD. (2013). Competition and Poverty Reduction: The OECD Global Forum on Competition debated. http://www.oecd.org/daf/competition/

[4].Omogi, J. A. (2014). Factors influencing participation of men in poverty reduction self help groups in slums. A case of Korogocho, Nairobi county, Kenya. In University of Nairobi Research Archive. University of Nairobi. http://erepository.uonbi.ac.ke/handle/11295/76819

[5].Park, S. (2012). Government and Policy. Seoul.analysis and practices.empirical evidance in public sector

[6].Purvis, B., Mao, Y., \& Robinson, D. (2019). Three pillars of sustainability: in search of conceptual origins. Sustainability Science, 14(3), 681-695. https://doi.org/10.1007/s11625-018-0627-5

[7].Reed, P. B., \& Howe, V. J. (2019). Defining and Classifying the Nonprofit Sector Notes prepared for the Advisory Group on Nonprofit Sector Research and Statistics in Canada. https://www3.carleton.ca/casr/Defining.pdf

[8].Roach, D. C. (2011). The impact of product management on SME performance. Journal of Small Business and Enterprise Development, 18(4), 695-714. 
[9].Schwienbacher, A., \& Larralde, B. (2012). Crowdfunding of Small Entrepreneurial Ventures. SSRN Electronic Journal, September 2010. https://doi.org/10.2139/ssrn.1699183

[10]. The Conversation. (2017). The role of NGOs in Africa: are they a force for good? The Conversation.

[11]. The World Bank. (2004). The Millennium Development Goals for Health rising challenges.

[12]. The World Bank. (2013). Provision of Social Services to the Poor and the Vulnerable in West Bank and Gaza. The World Bank.

[13]. The World Bank. (2018). Leveraging Urbanization for Rwanda's Economic Transformation. The World Bank.

[14]. United Nations. (2016). Ending Poverty by 2030 Depends on Social Development Commission's Policy Guidance, Secretary-General Says as Body’s General Debate Continues | Meetings Coverage and Press Releases. Meetings Coverage and Press Release.

[15]. WHO. (2012). The Report of a Multi-Country Study Health Systems in Africa Community Perceptions and Perspectives. 